\title{
Genetic divergence and evolution of Polyommatus coridon gennargenti (Lepidoptera: Lycaenidae) in Sardinia
}

\author{
A. MARCHI*, G. ADDIS, V. EXPOSÍTO HERMOSA $†$ \& R. CRNJAR $\ddagger$ \\ Dipartimento di Biologia Sperimentale, Sezione di Genetica and $\ddagger$ Sezione di Fisiologia Generale, Università di \\ Cagliari, Viale Poetto 1, 1-09126 Cagliari, Italy and †Pinos Baja, 60, E-28029 Madrid, Spain
}

\begin{abstract}
Electrophoretic analysis of 17 enzyme loci was carried out to assess the genetic differentiation and isolation of the Sardinian Polyommatus coridon gennargenti from $P$. c. apennina of peninsular Italy and the related taxon $P$. caelestissimus from central Spain. $P$. c. gennargenti is represented by a small, strongly inbred population, restricted to the central mountains of Sardinia, and probably derived from mainland populations as indicated by the reduction of genetic variation $(P=17.6$ per cent, $H=0.024)$ with respect to the continental populations $(P>52$ per cent, $H \geq 0.170)$. Absence of gene flow is indicated by the presence of alternative fixed alleles at the Aat, Gpi and Pgm loci and significant differences in allele frequencies at other loci, which distinguish the Sardinian population from $P$. c. apennina and $P$. caelestissimus. The genetic differentiation of $P$. $c$. gennargenti, as measured using Wright's $F_{\mathrm{ST}}$ values and Nei's genetic distances, suggests the evolution of the Sardinian taxon along an independent lineage, facilitated by isolation and the strict dependence of the butterflies on specific biotopes, thus confirming its taxonomic status.
\end{abstract}

Keywords: electrophoretic markers, genetic differentiation, geographical isolation, Polyommatus coridon, speciation.

\section{Introduction}

The chalk-hill blue butterfly Polyommatus (Lysandra) coridon is distributed throughout Europe, ranging from the Iberian peninsula across France, Germany and Italy, to Russia and Greece. In recent years the presence of $P$. coridon has been confirmed in the islands of Corsica (Schurian, 1977) and Sardinia (Leigheb, 1987, 1991). Everywhere the butterfly has a patchy distribution in colonies localized in suitable habitats on chalk and limestone. The species is monovoltine, with a prolonged emergence from mid-July to the end of September and can be found at altitudes from 200 to $2500 \mathrm{~m}$. Larval foodplants are various Leguminosae, mostly Hippocrepis comosa, Coronilla varia, C. minima and Astragalus glycyphyllos.

The $P$. coridon species complex represents among European butterflies one of the most challenging problems from both a taxonomic and evolutionary standpoint. In fact, the inherent difficulty of sorting out the different populations within the distribution

*Correspondence. of the complex has spawned a great number of names ranging from species to individual variation (Verity, 1916, 1939, 1943, 1951; Manley \& Allcard, 1970; Higgins, 1975; Higgins \& Riley, 1980; Higgins \& Hargreaves, 1983; de Bast, 1985; Schurian, 1988). The papers by de Lesse $(1970,1971)$, on the karyology of the complex, show a certain degree of variation with haploid chromosome numbers of $P$. coridon ranging from 87 to 90 , which supports the possibility that there is more than one species in the complex. The gene-enzyme electrophoretic technique has proved to be a powerful tool for approaching the systematics of $P$. coridon, allowing Mensi et al. (1988) to cluster some populations from Spain and others from southern France and Italy as two separate species.

The Sardinian $P$. coridon is represented by a small population restricted to a few localities of Barbagia around the central Gennargentu massif. The distinct morphological features of both males and females led Leigheb (1987) to propose a subspecific status (gennargenti) for the newly found taxon. This author has also suggested the possibility of a close relationship between $P$. c. gennargenti and $P$. caelestissimus 
from central Spain, on the basis of the similarity in the shining blue tinge of the upper surface of the male wing which clearly differentiates these two taxa from other populations of the $P$. coridon group.

In order to assess (i) whether the Sardinian $P . c$. gennargenit represents a genetically isolated population without gene exchange with the continental taxa and (ii) whether morphological differentiation is accompanied by sufficient genetic divergence to justify a change of its taxonomic status, we analysed the genetic variability of the Sardinian taxor of $P$. coridon and determined its phylogenetic relationships with two continental members of the group, based on the electrophoretic analysis of 17 enzyme loci.

\section{Materials and methods}

Specimens of $P$. c. gennargenti (Leigheb) were collected in Barbagia Seulo, Nuoro Province, Sardinia (altitude 800-1000 m; 20-25 July 1994), those of $P$. c. apennina (Poda) at Campo Imperatore, L'Aquila Province, Central Italy (altitude 1400-1600 m; 27 July 1994) and those of $P$. caelestissimus (Verity) at Tragacete, Cuenca Province, Central Spain (800 m; 20 August 1994). All specimens were personally carried or sent by express courier in a cool container $\left(15^{\circ} \mathrm{C}\right)$ to the laboratory and stored at $-70^{\circ} \mathrm{C}$ for later analysis. Voucher specimens were preserved for reference.

Seventeen enzyme loci were analysed by polyacrylamide gel electrophoresis. Individual butterflies were homogenized in $500 \mu \mathrm{L}$ of 10 per cent sucrose and $0.02 \mathrm{~mm}$ bromophenol blue. Enzymes tested and buffer systems used for each are listed in Table 1. Stairing recipes were prepared according to Shaw \& Prasad (1970) with slight modifications. Allozymes were ranked alphabetically in order of increasing mobility from the origin. Genetic and statistical analyses were performed using the BIOSYS-1 (Swofford \& Selander, 1981) and GENEPOP (Raymond \& Rousset, 1995) software. Hardy-Weinberg equilibrium was tested for each locus in all populations using Levene's (1949) correction for small samples. Unbiased exact probabilities were tested using a Markov chain method (Guo \& Thompson, 1992). Overall significance was tested by Fisher's combined probabilities method (Fisher, 1970). Genetic differentiation of populations was analysed by Wright's (1978) $F$ statistics and an unbiased estimate of Fisher's exact test on $\mathrm{R} \times \mathrm{C}$ contingency tables was performed using the Markov chain method of Guo \& Thompson (1992). Unbiased genetic similarity (I) and distance $(D)$ measures were obtained using Nei's $(1972,1978)$ formulae. A dendrogram was constructed by the unweighted pair group method (UPGMA) using Nei's unbiased genetic distances.

Table 1 Gene-enzyme systems, EC numbers (N.C.I.U.B.M.B., 1992) and number of loci studied

\begin{tabular}{lllll}
\hline Abbreviation & Name & EC no. & No. loci & Buffer \\
\cline { 5 - 6 } AAT & Aspartate aminotransferase & 2.6 .1 .1 & 1 & TBE $\dagger$ \\
ACO & Aconitate hydratase & 4.2 .1 .3 & 1 & TC $\$$ \\
AK & Adenylate kinase & 2.7 .4 .3 & 1 & TC \\
FUM & Fumarate hydratase & 4.2 .1 .2 & 1 & TBE \\
GPI & Glucose-6-phosphate isomerase & 5.3 .1 .9 & 1 & TBE \\
GPD & Glycerol-3-phosphate dehydrogenase & 1.1 .1 .8 & 1 & TC \\
G6PD & Glucose-6-phosphate dehydrogenase & 1.1 .1 .49 & 1 & TC \\
HK & Hexokinase & 2.7 .1 .1 & 1 & TBE \\
IDH & Isocitrate dehydrogenase & 1.1 .1 .42 & 2 & TC \\
LDH & Lactate dehydrogenase & 1.1 .1 .27 & 1 & TC \\
MDH & Malate dehydrogenase & 1.1 .1 .37 & 1 & TC \\
ME & Malic' enzyme & 1.1 .1 .40 & 1 & TBE \\
MPI & Mannose-6-phosphate isomerase & 5.3 .1 .8 & 1 & TBE \\
ODH & Octanol dehydrogenase & 1.1 .1 .73 & 1 & TBE \\
PGi & Phosphoglucomutase & 5.4 .2 .2 & 1 & TBE \\
PK & Pyruvate kinase & 2.7 .1 .40 & 1 & TBE \\
\hline
\end{tabular}

†Tris borate EDTA buffer (pH 8.9).

$\ddagger$ Tris citrate buffer ( $\mathrm{pH} \mathrm{7.1)}$. 
Table 2 Allele frequencies at 17 loci in Polyommatus caelestissimus from Spain and $P$. coridon from central Italy and Sardinia

\begin{tabular}{|c|c|c|c|c|}
\hline \multirow[b]{2}{*}{ Locus } & \multirow[b]{2}{*}{ Allele } & \multicolumn{3}{|c|}{ Population } \\
\hline & & Spain & $\begin{array}{c}\text { Central } \\
\text { Italy }\end{array}$ & Sardinia \\
\hline Aat & $\begin{array}{l}A \\
B \\
C \\
D\end{array}$ & $\begin{array}{c}n=12 \\
0.000 \\
0.958 \\
0.000 \\
0.042\end{array}$ & $\begin{array}{c}n=29 \\
0.000 \\
0.914 \\
0.034 \\
0.052\end{array}$ & $\begin{array}{c}n=40 \\
1.000 \\
0.000 \\
0.000 \\
0.000\end{array}$ \\
\hline Aco & $\begin{array}{l}A \\
B\end{array}$ & $\begin{array}{l}n=8 \\
1.000 \\
0.000\end{array}$ & $\begin{array}{c}n=18 \\
0.944 \\
0.056\end{array}$ & $\begin{array}{c}n=19 \\
0.000 \\
1.000\end{array}$ \\
\hline$A k$ & $A$ & $\begin{array}{l}n=7 \\
1.000\end{array}$ & $\begin{array}{c}n=15 \\
1.000\end{array}$ & $\begin{array}{c}n=21 \\
1.000\end{array}$ \\
\hline Fum & $A$ & $\begin{array}{c}n=12 \\
1.000\end{array}$ & $\begin{array}{c}n=29 \\
1.000\end{array}$ & $\begin{array}{c}n=40 \\
1.000\end{array}$ \\
\hline$G p i$ & $\begin{array}{l}A \\
B \\
C \\
D\end{array}$ & $\begin{array}{l}n=7 \\
0.071 \\
0.857 \\
0.000 \\
0.071\end{array}$ & $\begin{array}{c}n=15 \\
0.033 \\
0.867 \\
0.000 \\
0.100\end{array}$ & $\begin{array}{c}n=21 \\
0.000 \\
0.000 \\
1.000 \\
0.000\end{array}$ \\
\hline Gpd & $A$ & $\begin{array}{c}n=10 \\
1.000\end{array}$ & $\begin{array}{c}n=23 \\
1.000\end{array}$ & $\begin{array}{c}n=29 \\
1.000\end{array}$ \\
\hline G6pd & $\begin{array}{l}A \\
B\end{array}$ & $\begin{array}{c}n=10 \\
0.900 \\
0.100\end{array}$ & $\begin{array}{c}n=23 \\
1.000 \\
0.000\end{array}$ & $\begin{array}{c}n=29 \\
0.000 \\
1.000\end{array}$ \\
\hline$H k$ & $\begin{array}{l}A \\
B\end{array}$ & $\begin{array}{c}n=10 \\
0.700 \\
0.300\end{array}$ & $\begin{array}{c}n=22 \\
0.818 \\
0.182\end{array}$ & $\begin{array}{c}n=29 \\
1.000 \\
0.000\end{array}$ \\
\hline$I d h-1$ & $\begin{array}{l}A \\
B\end{array}$ & $\begin{array}{c}n=10 \\
0.950 \\
0.050\end{array}$ & $\begin{array}{c}n=23 \\
0.609 \\
0.391\end{array}$ & $\begin{array}{c}n=29 \\
0.931 \\
0.069\end{array}$ \\
\hline$I d h-2$ & $\begin{array}{l}A \\
B \\
C\end{array}$ & $\begin{array}{c}n=10 \\
0.000 \\
1.000 \\
0.000\end{array}$ & $\begin{array}{c}n=23 \\
0.022 \\
0.935 \\
0.043\end{array}$ & $\begin{array}{c}n=29 \\
0.000 \\
1.000 \\
0.000\end{array}$ \\
\hline$L d h$ & $\begin{array}{l}A \\
B\end{array}$ & $\begin{array}{l}n=5 \\
0.000 \\
1.000\end{array}$ & $\begin{array}{c}n=10 \\
0.450 \\
0.550\end{array}$ & $\begin{array}{c}n=11 \\
0.000 \\
1.000\end{array}$ \\
\hline$M d h$ & $\begin{array}{l}A \\
B \\
C\end{array}$ & $\begin{array}{l}n=9 \\
0.889 \\
0.111 \\
0.000\end{array}$ & $\begin{array}{c}n=23 \\
0.261 \\
0.696 \\
0.043\end{array}$ & $\begin{array}{c}n=29 \\
0.948 \\
0.052 \\
0.000\end{array}$ \\
\hline$M e$ & $\begin{array}{l}A \\
B \\
C\end{array}$ & $\begin{array}{l}n=9 \\
0.000 \\
0.889 \\
0.111\end{array}$ & $\begin{array}{c}n=22 \\
0.023 \\
0.955 \\
0.023\end{array}$ & $\begin{array}{c}n=32 \\
0.000 \\
0.000 \\
1.000\end{array}$ \\
\hline
\end{tabular}

(C) The Genetical Society of Great Britain, Heredity, 77, 16-22. 
Table 2 Continued

\begin{tabular}{|c|c|c|c|c|}
\hline \multirow[b]{2}{*}{ Locus } & \multirow[b]{2}{*}{ Allele } & \multicolumn{3}{|c|}{ Population } \\
\hline & & Spain & $\begin{array}{l}\text { Central } \\
\text { Italy }\end{array}$ & Sardinia \\
\hline \multirow[t]{9}{*}{$M p i$} & & $n=12$ & $n=29$ & $n=40$ \\
\hline & $A$ & 0.000 & 0.103 & 0.000 \\
\hline & $B$ & 0.000 & 0.103 & 0.000 \\
\hline & $C$ & 0.000 & 0.017 & 0.000 \\
\hline & $D$ & 0.250 & 0.190 & 0.000 \\
\hline & $E$ & 0.000 & 0.017 & 0.000 \\
\hline & $F$ & 0.000 & 0.034 & 0.000 \\
\hline & $G$ & 0.708 & 0.534 & 1.000 \\
\hline & $H$ & 0.042 & 0.000 & 0.000 \\
\hline \multirow[t]{5}{*}{ Odh } & & $n=11$ & $n=29$ & $n=40$ \\
\hline & $A$ & 0.091 & 0.000 & 0.000 \\
\hline & $B$ & 0.864 & 0.983 & 1.000 \\
\hline & $C$ & 0.000 & 0.017 & 0.000 \\
\hline & $D$ & 0.045 & 0.000 & 0.000 \\
\hline \multirow[t]{7}{*}{$P g m$} & & $n=12$ & $n=29$ & $n=40$ \\
\hline & $A$ & 0.000 & 0.000 & 1.000 \\
\hline & $B$ & 0.000 & 0.000 & 0.000 \\
\hline & $C$ & 0.250 & 0.121 & 0.000 \\
\hline & $D$ & 0.500 & 0.810 & 0.000 \\
\hline & $E$ & 0.250 & 0.052 & 0.000 \\
\hline & $F$ & 0.000 & 0.017 & 0.000 \\
\hline \multirow[t]{3}{*}{$P k$} & & $n=10$ & $n=23$ & $n=29$ \\
\hline & A & 1.000 & 0.978 & 0.914 \\
\hline & $B$ & 0.000 & 0.022 & 0.086 \\
\hline
\end{tabular}

$n$, no. individuals tested for each population.

\section{Results}

Allelic frequencies at the 17 loci analysed are reported in Table 2. A total of 50 alleles were identified at all loci. Two loci, $A k$ and $G p d$, were found to be monomorphic in all samples based on the 95 per cent criterion. All the other loci were polymorphic in at least one population. More than 50 per cent of loci were polymorphic in the continental $P$. $c$. apennina and $P$. caelestissimus whereas most loci were monomorphic in the Sardinian $P . \quad c$. gennargenti $(P=17.6$ per cent) (Table 3$)$. The mean heterozygosity of the Sardinian sample was significantly lower $(H=0.024, P<0.01)$ than the continental samples $(H=0.185-0.170)$. Alleles at all loci were in Hardy-Weinberg equilibrium $(P>0.05)$ except for $H k$ and $M d h$ in $P$. c. apennina and $O d h$ in $P$. caelestissimus because of an excess of homozygotes. However, $\chi^{2}$ values for these loci were not significant at the 0.01 probability level. Moreover, Hardy-
Weinberg equilibrium was not rejected when testing across loci within each sample $(P>0.7)$ and with the overall test for all loci in all populations $(P>0.9)$.

Alternative fixed alleles at the Aat, Gpi and Pgm loci were diagnostic for the Sardinian $P$. c. gennargenti. Allelic frequencies at the loci $\mathrm{Aco}, \mathrm{Me}$ and $\mathrm{Mpi}$ were also significantly different in Sardinian and continental samples $(P<0.0005)$. These loci gave the major contribution to the distinction between samples as shown by $F_{\mathrm{ST}}$ values ranging from 0.923 for $A c o$ to 0.129 for $M p i$ (Table 4). The mean $F_{\mathrm{ST}}$ value of 0.521 indicates that at least 52 per cent of the total variability in the samples is attributable to divergence among populations. The high value of $F_{\text {ST }}$ was attributable mainly to the Sardinian population because removing it from the analysis substantially decreased the $F_{\mathrm{ST}}$ value $\left(F_{\mathrm{ST}}=0.120\right)$.

Nei's coefficient of genetic distance $(D)$ between the Sardinian and the central Italian $P$. $c$. apennina was 0.434 , and between the Sardinian and Spanish 
Table 3 Genetic variability at 17 loci in the three samples of Polyommatus

\begin{tabular}{lcccc}
\hline Taxon & $\begin{array}{c}\text { Sample } \\
\text { size per } \\
\text { locus }\end{array}$ & $\begin{array}{c}\text { Mean no. } \\
\text { alleles } \\
\text { per locus }\end{array}$ & $\begin{array}{c}\% \\
\text { polymorphic } \\
\text { loci }\end{array}$ & $\begin{array}{c}\text { Heterozygosity } \\
\text { (mean } \pm \mathrm{SE} \text { ) }\end{array}$ \\
\hline P. coridon & 22.6 & 2.5 & 58.80 & $0.185 \pm 0.045$ \\
$P$. c. gennargenti & 29.8 & 1.2 & 17.60 & $0.024 \pm 0.113$ \\
$P$. caelestissimus & 9.6 & 1.8 & 52.90 & $0.170 \pm 0.051$ \\
\hline
\end{tabular}

A locus is considered to be monomorphic if the frequency of the common allele is greater than 0.95 .

Table 4 Summary of $F$-statistics at all loci of Polyommatus

\begin{tabular}{lrrr}
\hline Locus & \multicolumn{1}{c}{$F_{\mathrm{IS}}$} & \multicolumn{1}{c}{$F_{\mathrm{IT}}$} & $F_{\mathrm{ST}}$ \\
\hline Aat & -0.061 & 0.829 & 0.839 \\
Aco & -0.059 & 0.919 & 0.923 \\
Gpi & -0.121 & 0.668 & 0.704 \\
G6pd & -0.111 & -0.034 & 0.069 \\
Hk & -0.090 & 0.033 & 0.113 \\
Idh-1 & 0.163 & 0.308 & 0.174 \\
Idh-2 & -0.053 & -0.017 & 0.034 \\
Ldh & -0.010 & 0.346 & 0.353 \\
Me & -0.097 & 0.782 & 0.802 \\
$M p i$ & -0.105 & 0.037 & 0.129 \\
Mdh & 0.209 & 0.544 & 0.423 \\
Odh & 0.548 & 0.576 & 0.061 \\
Pgm & 0.075 & 0.564 & 0.529 \\
Pk & -0.079 & -0.037 & 0.039 \\
Mean & 0.024 & 0.532 & 0.521 \\
\hline
\end{tabular}

taxa it was 0.337 (Table 5). Nei's identity values were 0.648 and 0.714 , respectively. The genetic distance between the two continental populations was 0.054. UPGMA cluster analysis based on Nei's unbiased genetic distances (cophenetic correlation coefficient $=0.96$ ) confirmed the divergence of the Sardinian taxon from the two continental taxa (Table 5, Fig. 1).

\section{Discussion}

The Sardinian $P$. c. gennargenti is characterized by a high proportion of monomorphic loci and very low heterozygosity, with all loci in Hardy-Weinberg equilibrium. From the analysis of allozymic data this taxon appears as an isolated, strongly inbred population, with a very low level of genetic variation when compared to the continental $P$. c. apennina and $P$. caelestissimus. Reduction of genetic variability has been observed in peripheral isolated colonies of the
Table 5 Nei's genetic identity (above diagonal) and distance (below diagonal)

\begin{tabular}{lccc}
\hline & 1 & 2 & 3 \\
\hline 1 Polyommatus coridon apennina & - & 0.648 & 0.947 \\
2 P. c. gennargenti & 0.434 & - & 0.714 \\
3 P. caelestissimus & 0.054 & 0.337 & - \\
\hline
\end{tabular}

montane butterfly, Parnassius mnemosyne in southern France (Descimon \& Napolitano, 1993) and, generally, it is a common feature of peripheral populations with respect to the source area of the species. In this perspective, $P$. c . gennargenti has probably derived from mainland populations of $P$. coridon.

The presence of diagnostic alleles and significant differences in allele frequencies at several loci indicates lack of gene flow between the island and the continental populations, suggesting that the Sardinian taxon is evolving independently from the mainland taxa. This conclusion is in agreement with the taxonomic distinction of the Sardinian taxon from the continental $P$. coridon proposed by Leigheb $(1987,1991)$ in his original description of $P . c$. gennargenti and based on morphological differences in wing coloration. Genetic drift probably plays a major role in the genetic differentiation of the Sardinian taxon favoured by geographical isolation and strong inbreeding within a small and subdivided population occupying a limited habitat area, probably not exceeding $20 \mathrm{~km}^{2}$ (Crnjar, unpublished observation). Moreover, genetic isolation is not likely to be affected by migration, because $P$. coridon is generally a poor flyer and shows behaviour typical of sedentary butterflies (Eitschberger et al., 1991).

Values of Nei's genetic distances between the Sardinian $P$. c. gennargenti and the continental taxa, ranging from 0.337 to 0.434 , are higher than those found at intraspecific level, among geographically

(C) The Genetical Society of Great Britain, Heredity, 77, 16-22. 


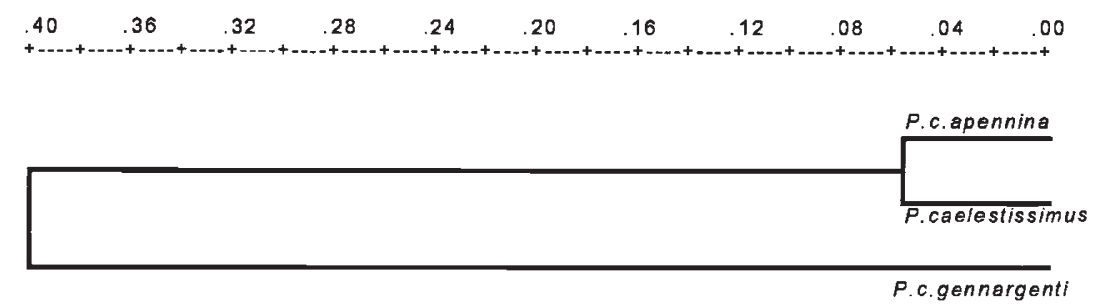

Fig. 1 UPGMA dendrogram using unbiased Nei's genetic distances.

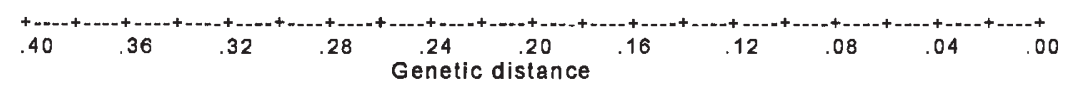

isolated populations of $P$. coridon from peninsular Italy $(D \leq 0.1)$, and at interspecific level, between $P$. coridon and the closely related $P$. albicans species complex $(D \approx 0.25)$ (Mensi et al., 1988). In another taxonomically controversial species group of the same Papilionidea superfamily, the Pieris napi complex, interspecific genetic distances were estimated to be around 0.35 or lower (Geiger \& Scholl, 1985). However, if the biological species concept is applied, electrophoretic data alone do not allow us to propose a taxonomic status higher than subspecies for the Sardinian taxon. On the other hand, although reproductive isolation cannot be tested among these allopatric populations, our estimates of genetic identities between $P$. $c$. gennargenti and the two continental taxa $(I=0.648$ and 0.714$)$ are below the 0.85 value proposed as discriminating separate species (Thorpe, 1982), thus pointing to the genetic isolation of the Sardinian $P$. coridon. The diagnostic differences at morphological and biochemical levels would then favour the hypothesis of species status from at least the phylogenetic point of view (Wiley, 1978). Similar conclusions have been drawn for other allopatric taxa of Lepidoptera (Geiger \& Scholl, 1985).

Calculation of divergence time from genetic distances gives estimates ranging from 6 to $1.6 \mathrm{Myr}$ depending on the calibration used, $D=1$ equivalent to 18.9 Myr (Wilson et al., 1977) or $D=1$ equivalent to $5 \mathrm{Myr}$ (Nei, 1972), respectively. The cladogenetic event leading to the Sardinian lineage would have occurred after the separation of the Sardo-Corsican microplate from the continental landmass (about $30 \mathrm{Myr}$ ago), probably after one of the successive marine regressions, from late Miocene to Pliocene, that brought 'Cor-Sardinia' in contact with northern Italy and southern France 5.7-0.23 Myr ago (Arias et al., 1980; Cita, 1980).

Given the morphological similarities between males and the relative incidence of blue-form females (absolute for gennargenti and significantly higher for caelestissimus as compared to other taxa in the coridon group), Leigheb $(1987,1991)$ speculated that gennargenti could belong to caelestissimus, thus confirming the faunal affinities of the Iberian Peninsula with Sardinia and Corsica. However, the differences in Nei's genetic distance between $P$. $c$. gennargenti and the two continental taxa, $P$. caelestissimus $(D=0.337)$ and $P$. c c apennina $(D=0.434)$ are not significant $(P>0.05)$ and similarities between the Sardinian and Spanish taxa could be the result of morphological convergence.

The genetic distance between $P$. caelestissimus and $P$. c. apennina is very low $(D=0.054)$, indicating a high level of gene flow between the two. This last result is quite different from that reported by Mensi et al. (1988) based on an electrophoretic study of 16 enzyme loci. They found significant differences in allele frequency at the G6pd locus and an alternative allele at the $P k-2$ locus between nine Spanish populations (from northern and central Spain) attributed to $P$. caelestissimus and six populations of $P$. coridon from southern France and peninsular Italy. The genetic distance between the two groups was 0.430 , far higher than that reported here. A possible explanation of the discrepancy could be the origin of the populations sampled. In fact, all Spanish populations but one investigated by Mensi and co-workers came from different areas of Spain outside the distribution range of $P$. caelestissimus, which is limited to the Montes Universales in central Spain. Moreover, experimental bias caused by the small sample size cannot be excluded. Considering the wide distribution and relic characteristics of this species group, additional investigation will be necessary to clarify the phylogenetic relationship among all the member of the $P$. coridon complex.

Finally, it should be noted that the low level of genetic variation and the biological and ecological characteristics of $P . c$. gennargenti could eventually 
impair the survival of this butterfly following environmental and climatic changes, thus making the Sardinian taxon vulnerable to extinction.

\section{Acknowledgements}

We wish to thank Mr Daniele Baiocchi (Rome) for kindly providing the $P$. $c$. apennina specimens.

\section{References}

ARIAS, C., AZZAROl, A., BIGAZZI, G. AND BONADONNA, F. P. 1980. Magnetostratigraphy and Pliocene-Pleistocene boundary in Italy. Quater. Res., 13, 65-74.

DE BAST, B. 1985. La notion d'espéce dans le genre Lysandra Hemming, 1933 (Lepidoptera Lycaenidae). Linn. Belg., 10, 98-110.

CITA, M. B. 1980. Quand la Méditerranée était asséchée. La Recherche, 107, 26-35.

DESCIMON H. AND NAPOLITANO, M. 1993. Enzyme polymorphism, wing pattern variability, and geographical isolation in an endangered butterfly species. Biol. Conserv., 66, 117-123.

EITSCHBERGER, U., REINARDT, R. AND STEINIGER, H. 1991. Wanderfalter in Europa. Atalanta, 22, 18-67.

FISHER, R. A. 1970. Statistical Methods for Research Workers, 14th edn. Oliver \& Boyd, Edinburgh.

GEIGER, H. J. AND SCHOLL, A. 1985. Systematics and evolution of holarctic Pierinae (Lepidoptera). An enzyme electrophoretic approach. Experientia, 41, 24-29.

GUO, S. W. AND THOMPSON, E. A. 1992. Performing the exact test of Hardy-Weinberg proportions for multiple alleles. Biometrics, 48, 361-372.

HIGGINS, L. G. 1975. The Classification of European Butterflies. Collins, London.

Higgins, L. G. AND HARgREAVES, B. 1983. The Butterflies of Britain and Europe. Collins, London.

Higgins, L. G. AND RILEy, N. D. 1980. A Field Guide to the Butterflies of Britain and Europe. Collins, London.

LEIGHEB, G. 1987. Lysandra coridon ssp. gennargenti nova (Lepidoptera, Lycaenidae) nuovo licenide della Sardegna. Boll. Mus. Region. Sci. Nat. Torino, 5, 447-454.

Lergheb, G. 1991. La femmina di Polyommatus (Lysandra) coridon gennargenti (Leigheb, 1987) (Lepidoptera, Lycaenidae). Boll. Mus. Region. Sci. Nat. Torino, 9, 369-373.

DE LESSE, H. 1970. Les nombres de chromosomes à l'appui d'une systématique du groupe de Lysandra coridon. Alexanor, 6, 203-224.

DE LESSE, H. 1971. Variation géographique des nombres chromosomes chez les Lycaenidae (Lépidoptères). $C$. R. Soc. Biogéog., 418, 33-38.
LEVENE, H. 1949. On a matching problem arising in genetics. Ann. Math. Stat., 20, 91-94.

MANley, w. B. L. AND Allcard, H. G. 1970. A Field Guide to the Butterflies and Burnets of Spain. Classey, Hampton, U.K.

MENSI, P., LATTES, A., SAlvidio, S. AND BalletTo, E. 1988. Taxonomy, evolutionary biology and biogeography of South European Polyommatus coridon (Lepidoptera: Lycaenidae). Zool. J. Linn. Soc., 93, 259-271.

NeI, M. 1972. Genetic distance between populations. Am. Nat., 106, 283-292.

NEI, M. 1978. Estimation of average heterozygosity and genetic distance from a small number of individuals. Genetics, 89, 583-590.

NOMENCLATURE COMMITTEE OF THE INTERNATIONAL UNION OF BIOCHEMISTRY AND MOLECULAR BIOLOGY 1992. Enzyme Nomenclature, 6th edn. Academic Press, Orlando, FA.

RAYMOND, M. AND ROUSSET, F. 1995. GENEPOP (ver. 1.2), a population genetics software for exact tests and ecumenicism. J. Hered., 86, 248-249.

SCHURIAN, K. 1977. Eine neue Unterart von Lysandra coridon Poda (Lep. Lycaenidae). Entomol. Z., 87, 13-18.

SCHURIAN, K. 1988. Neueinteilung des Subgenus Lysandra der Gattung Polyommatus Latreille (Lep., Lycaenidae). Entomol. Z., 98, 129-144.

SHAW, C. R. AND PRASAD, R. 1970 Starch gel electrophoresis of enzymes - A compilation of recipes. Biochem. Genet., 4, 297-320.

SWOFFORD, D. L. AND SELANDER, R. B. 1981. BIOSYS-1. A FORTRAN program for the comprehensive analysis of electrophoretic data in population genetics and systematics. J. Hered., 72, 281-283.

THORPE, J. P. 1982. The molecular clock hypothesis: biochemical evolution, genetic differentiation and systematics. Ann. Rev. Ecol. Syst., 13, 139-168.

VERITY, R. 1916. Deux Lycenidae confondus sous le nom de L. (Agriades) coridon Poda. Ann. Soc. Entomol. France, 84, 514-520.

VERITY, R. 1939. Essai sur la distinction des espèces du groupe de Lysandra coridon Poda. Lambillonea, 39, 210-222.

verity, R. 1943. Farfalle Diurne d'Italia, vol. 2, Divisione Lycaenidae. Marzocco, Florence, Italy.

VERITY, R. 1951. Variations géographiques et saisonnières des Papillons diurnes en France. Rev. Fr. Lepidopt., 1, 166-172.

WILEY, E. O. 1978. The evolutionary species concept reconsidered. Syst. Zool., 27, 17-26.

WILSON, A. C., CARLSON, S. S. AND WHITE, T. J. 1977. Biochemical evolution. Ann. Rev Biochem., 46, 573-639.

Wright, s. 1978. Evolution and the Genetics of Populations, vol. 4, Variability Within and Among Natural Populations. University of Chicago Press, Chicago. 